\title{
The emergence and evolution of optimistic expectations in schoolchildren
}

\author{
Carolina Falcón ${ }^{1}$, Santos Orejudo ${ }^{2 *}$, Teresa Fernández Turrado ${ }^{2}$ and Francisco Javier Zarza ${ }^{3}$ \\ 1 Departamento de Ciencias de la Educación. Universidad de Zaragoza (Spain). \\ 2 Departamento de Psicología y Sociología. Universidad de Zaragoza (Spain). \\ 3 Departamento de Expresión Musical, Plástica y Corporal. Universidad de Zaragoza (Spain).
}

\begin{abstract}
Título: Emergencia y evolución de las expectativas optimistas en niños de educación primaria.

Resumen: $\mathrm{Al}$ aproximarnos al estudio del optimismo en niños, encontramos la aparición de un sesgo que les lleva a elaborar predicciones optimistas. Con esta investigación pretendemos conocer los cambios que se producen en la etapa de educación primaria (6-12 años), tanto en la aparición del sesgo optimista como en la explicaciones que los niños hacen de sus predicciones. Han participado un total de 77 alumnos a los que de manera individual y mediante un formato de entrevista piagetiana se les ha pedido realizar predicciones sobre diferentes situaciones hipotéticas. Tras un primer análisis para establecer si la predicción del niño implicaba un cambio en sentido optimista o pesimista, se han categorizado las respuestas ofrecidas por los niños al argumentar su predicción. Los resultados muestran que los participantes en esta investigación consideran más probable el cambio positivo para eventos psicológicos o híbridos que para los biológicos, y que estos cambios son más probables entre los niños de menor edad. En cuanto a las explicaciones de estos cambios, los niños consideran que la propia naturaleza o el paso del tiempo pueden ser responsables de los mismos sin mediar otro tipo de intervenciones. Igualmente, razones parecidas suelen dar los niños mayores para explicar el mantenimiento de las situaciones.

Palabras clave: Sesgo optimista, optimismo; educación primaria, predicciones, atribuciones.
\end{abstract}

\section{Introduction}

Optimism is one of the psychological constructs which has awakened the greatest amount of scholarly interest in recent years, with studies in such diverse fields as illness survival or school-related stress. To a great extent, this construct's success is one of the main areas of Positive Psychology, where it is associated with a series of tools and resources designed to help people deal with stressors (Roberts, Brown, Jonson \& Reinke, 2005; Seligman \& Csiksmihalyi, 2000); moreover, certain factors have favored its marketing outside scientific circles (Pérez, 2012). Although the impact of optimism studies is undeniable, their success also implies some specific risks. The most salient one is probably the lack of depth and rigor displayed in trivial sayings such as "simply be positive" or "you should start thinking positive", catch phrases with which people are advised to confront change. Instead we find that the best way one can proceed is by applying scientific tools to study different aspects of the emergence of optimism in the individual, along with its evolution and changes, both in day-to-day life as well as in a therapeutic context.

Although a series of authors working in the area of sociocognitive theory and others (Chang, 2002; Roberts et al., 2005; Romero, 2005) have done a great job in establishing

* Dirección para correspondencia [Correspondence address]: Santos Orejudo. Departamento de Psicología y Sociología. Universidad de Zaragoza. C/ Pedro Cerbuna, 12. 50009. Zaragoza (Spain). E-mail: sorejudo@unizar.es
Abstract: When we study optimism in children, we note the temporary emergence of a bias that leads them to make optimistic predictions. In this study we intend to learn more about changes that can be observed in the optimistic bias of 6- to 12-year old schoolchildren when they predict future events, and in the way they justify those predictions. A total of $77 \mathrm{pu}$ pils participated in this study; we evaluated each one of them individually with a Piagetian interview, asking them to formulate predictions about a series of hypothetical situations. After analyzing whether a child's prediction implied that the situation would maintain itself or would change for better or for worse, we classified the justifications they provided for their predictions. Results show that these subjects regarded positive change as more likely in the case of psychological or hybrid events than for purely biological ones, and that younger children tended to display a greater bias in favor of the likelihood of positive change. These younger children justified their predictions stating that nature or the passing of time could be responsible for the changes, without needing further intervention on the part of other agents. Older children, on the other hand, tended to provide similar kinds of explanations to justify their expectation of stasis.

Keywords: optimism bias; optimism; primary education; predictions; attributions

the theoretical framework for optimism studies, we found that the least explored field therein is the emergence and evolution of optimistic beliefs. It is nevertheless a particularly relevant field, since it is easier to intervene upon optimism during the stage in which beliefs are being formed, rather than when they have already become stable (Orejudo \& Teruel, 2009).

Until now, most studies about dispositional optimism (Scheier \& Carver, 1992; 2002) and optimistic explanatory style (Gillham, Shatté, Reivich \& Seligman, 2002) have been principally carried out on adults and adolescents, i.e. on people who have already attained a certain degree of stability in their beliefs. A great deal of theoretical groundwork has described adolescence as the period in which beliefs are stabilized and individual differences emerge (Brissette, Scheier \& Carver, 2002); the formal operational stage is the one in which major changes in the concept of self, in attributive reasoning and in beliefs about the future take place. Just as in other aspects of infant and adolescent development (Ato, Galián \& Huescar, 2007), researchers here also take the important influence of family and environmental variables on the evolution of these beliefs into account (Chorpita y Barlow, 1998; Orejudo, Puyuelo, Fernández-Turrado y Ramos, 2012).

In this study we point out the importance of analyzing such changes in optimism in earlier developmental stages. Apart from ascertaining categorical differences that can be associated with such variables, the interest of this study would lie in our attempt to extend current knowledge about 
the way certain changes take place in the course of the period when they initially emerge.

Reviews in this field suggest that the cognitive model of transition to attributional theories in adults could already start holding sway in the mid-schoolgrades, i.e. from the age of 10 onwards (Gillham, Reivich \& Shatté, 2002). Children would be able to justify any event by resorting to a greater number of variables, thus taking a wider range of causes into account - causes lying either in themselves or originating in third parties. In that stage of cognitive transition, children would also start to include the dimensions of stability and globality in their concept of personal abilities and personality traits - for example, when talk about intelligence, selfishness or generosity. This process reaches a stage of maturity around the age of twelve (Cole et al., 2008).

Prior to those ages, a series of studies have revealed a certain optimistic bias in the predictions made by preschoolers or by children in the first years of elementary education. Thus, a groundbreaking study by Lockhart, Chang \& Story (2002) found that the youngest children, ages 9 and under, were unconditionally positive in their judgments related to the future, and they found no differences in the children's optimistic beliefs regarding the type of negative trait or event they were being questioned about.

The most commonly displayed characteristic in those early ages was protective optimism - protective toward themselves and toward others. That state of exaggerated optimism led the children to perceive personality traits and abilities as much more malleable and less stable than adults did. Changes were always expected to occur in the desired sense, and the children thought they could occur if they merely wished for them. Lockart et al. (2002) pointed out that such an argumentative tendency makes more sense when it is considered from the angle of evolutionary psychology, which views optimism as an adaptive tool.

In this developmental phase, the child needs to acquire a great number of new cognitive tools and behavior strategies - a slow, painstaking task that requires consistency and motivation free of any negative feelings (Lockhart et al., 2002). Similar results regarding optimistic bias can be found in other studies by the same authors (Lockhart, Keil \& Aw, 2013; Lockhart, Nakashima, Inagaki \& Keil, 2008) and in further investigations of the attribution of intentions to third parties (Boseovski, 2012; Sato \& Wakebe, 2014).

Boseovski (2010) highlights the relevance of such optimistic slants: they form part of social reasoning and play a relevant role in the adaptation process undergone by children in those ages. Optimistic bias exerts an influence on social reasoning and on relations among peers, as well as on the motivation and formation of judgments and stereotypes about others. Such bias is likewise considered to play a fundamental role in the preservation of the child's motivation to learn, contributing to a high sense of self-efficacy. Development psychology considers that a child's cognitive resources concentrate their processing capacities on certain types of information.
The cultural practices and attribution styles of adults visá-vis the behavior of children (based on internal factors in the case of positive events, and on external factors for the negative ones) would help determine which elements are the most notable in a child's environment. Thus it is assumed that optimistic beliefs have a double origin: an development dimension, to be sure, but also a sensitivity to cultural and contextual differences that increases with age (Deeb, Segall, Birnbaum, Ben-Eliyahu \& Diesendruck, 2011; Lockhart et al., 2008).

This positive - and, often, unrealistic - bias in the youngest children would become a maladaptive trait if it persisted later on. As children grow older, they start developing a perception of stability in terms of abilities and personality traits. They start considering their own traits and those of others as something less changeable, more permanent; negative aspects are not only perceived as such, but also as relatively immutable despite the passing of time. Therefore, in parallel with children's psychological development, the dimension of stability would emerge as the next most relevant attributional style: greater age-related differences are notable along that dimension than in globality and internality (Cole et al., 2008). From that developmental moment onwards, i.e. from the age of 10-11 on, the first pessimistic feelings emerge (Lockhart et al., 2002), and optimistic bias tends to disappear (Boseovski, 2010).

An additional element that can help us understand the children's reasoning during these stages is essentialism. Thus, children tend to found their explanations on the viewpoint that human beings possess a determined set of traits and characteristics that are a constituent part of their being (Diesendruck \& Eldror, 2011; Gelman, 2004; Gelman, Heyman \& Legare, 2007; Newman, Bloom \& Knobe, 2014). Essentialism postulates that children construct their concepts on the basis of naïve theories, and not just through associative learning strategies or by progressing solely from the perceptual to the conceptual; instead, all of these aspects have simultaneous roles to play (Karmiloff-Smith, 1994). Within the perspective of essentialism, a child's implicit theories and specific beliefs in a certain domain are that which guides his/her categorization process. When justifying their reasoning, children would resort to optimistic bias, positing that positive traits are essential attributes and not modifiable (entity theories), whereas negative traits would be considered modifiable (incremental theories; cf. Boseovski, 2010; Newman et al., 2014).

Thus, the role of perceptual resemblance would be relegated to a secondary level when we consider that theoretical keys to understanding, based on attributions of causality and on beliefs about different areas of life, are what leads individuals to detect and prioritize certain perceptions over others (Peraita, 2009). Even preschoolers make use of information that lies beyond the obvious - for example, when they learn words, when they apply their acquired knowledge to other categories, and when they form explanations following their own infant logic, etc. Heyman and Gelman (2000) 
suggest that children have a pronounced early tendency to explore and make inferences about aspects of reality that are neither visible nor obvious.

On the one hand, the aforementioned studies (Gelman, 2004; Gelman, Heyman \& Legare, 2007; Lockhart et al., 2002) evaluated a series of situations or personal traits whose content had a determining influence on the tendency of subjects' beliefs when they were asked to predict an optimistic or pessimistic future. The perceived stability/mutability of personal traits is clearly affected by the type and nature thereof - more concretely, by their origin: whether they are more of a biological or psychological nature (and this fits in well with the essentialist viewpoint).

Heyman \& Gelman (2000) found that preschoolers are already capable of distinguishing between physical and psychological traits, although at that early age they are only capable of emitting systematic judgments about physical ones. Moreover, they differentiate natural from non-natural traits by applying a greater amount of determinism when they characterize their perceived image of different people. As evaluated traits become more psychological, and as interviewed subjects grow older ( 9 to 10 yrs. old), their judgments become less unidimensional, and they start attributing causes to a wider range of non-determinant possibilities such as the effects exerted by society, family environment

This last study fits in well with the aforementioned one by Karmiloff-Smith (1994), which described the way young children use natural-category essentialism to organize their knowledge in modules (Karmiloff-Smith, 1994), and it also has parallels with studies that explain how children confer a clear innateness to certain social categories that might seem biologically determined, such as race or gender (Del Río \& Strasser, 2007).

Although studies of the evolution of optimism in children have amassed a large body of knowledge, and although the existence of optimistic bias in the different knowledge areas of children is a well-established fact, it would still be relevant to go into further depth on a number of aspects related with specific areas, individual differences related to those areas, prevalence data (Boseovski, 2010).

In this study we investigate optimist beliefs in Spanish children: no studies in this domain of knowledge have been previously conducted in our country. We refer to the study by Lockhart et al. (2002) as our methodological point of departure and of reference. Our objectives are the following: 1) to analyze the presence of optimistic bias in children when they evaluate positive and negative events, and 2) to identify the justifications they provide for each one of their predictions, and to interpret the results. Our hypothesis of departure, based on the study by Lockhart et al. (2002), is the following: since younger children do not tend to differentiate certain traits from others in terms of their deterministic weight, they would not view biological vs. psychological traits as very different in terms of stability either. Older-aged children, however, would ascribe a greater stability to biolog- ical traits, and possibly propound more realistic arguments to justify their predictions.

\section{Method}

\section{Participants}

A sample of 77 schoolchildren ages 7 to 12 was selected from 2nd grade, 4th grade and 6th grade classes in an elementary school in Zaragoza. The natural cohorts were subsequently classified by age in three groups for investigation. Group A (7 and 8 yrs. old) contained 25 participants $(32.5 \%$ of the total), of whom 7 were female and 18 were male. Group B (9 and 10 yrs. old) contained 29 participants (37.7\% of total), of which 11 were female and 18 were male. Finally, Group C (11 and 12 yrs. old) contained 23 participants $(29.5 \%$ of total), of whom 11 were female and 12 were male. In total, the number of girls, i.e. $29(37.7 \%$ of total), was lower than the number of boys, i.e. $48(62.3 \%)$, whereby distribution was similar in all three groups $\left(\chi^{2}=2.007, p=.367\right)$.

The sample comprised different socio-economic levels: immigrants, pupils in need of additional tutoring. Concretely, 47 children came from Spanish families $(61.0 \%)$ and 30 children from families of immigrants $(39.0 \%)$. No relation was found between family origin and level of schooling $\left(\chi_{2}^{2}=1.853, p=.398\right)$.

\section{Instrument}

In an individual semi-structured interview, we presented three stories to the children, following the procedure previously applied by Lockhart et al. (2002). The Lockhart study had used a total of 12 stories: 6 positive ones and 6 negative ones. In our case we only used three negative stories in total; children's predictions are expected to be different in the case of positive or negative stories, and their optimistic bias would be more evident in negative ones. In all three stories, the main character displays a trait that he wants changed, a trait that is considered negative (i.e. not desirable) and which most people would not want to possess.

The material was elaborated to encourage the participants to identify with the characters. The negative aspect described in Story No. 1 - the loss of a finger - is thoroughly influenced by nature and therefore cannot be readily modified; Story No. 2 possesses both components, a physical one and a psychological one (learning difficulties); Story No. 3 presents a problem whose origin is fundamentally psychological - the fact of being a messy person - and which is, therefore less subject to determinism.

In each one of the three stories, the negative trait was presented as having arisen when the main character was 5 five years old, and it was emphasized that the trait remained stable until the age of 10 . Participants were then asked to predict what the character's situation would be like when he was 21 . The children were asked to choose among three re- 
sponse options: extreme positive change, slight positive change, or no change at all (i.e. stability).

A pictorial illustration was provided for each stage in the story and for each one of the potential responses. Facial expressions in all drawings were neutral. After having chosen a response option, participants were asked to provide a reasoned explanation to justify why they had chosen it. Those responses, recorded on audio, were transformed into quantifiable data by categorizing the children's justifications. To better explain our tool to the reader, we present the outline of Story No. 2 on the subject of learning difficulties, with its three alternative response options:

Hybrid trait (biological-psychological)

"This is Juan's true story:

- When Juan was 5 years old, he had great difficulties in learning the things they taught him in school. He wanted to be smarter. He would often imagine that he was capable of learning many things, and that he was a wise person.

- When Juan was 10, he knew more things than when he was 5 , but he still had many problems with learning things in school, as compared to other kids in his class. He still would dream of being a smart boy. He wanted to excel at school.

- Now Juan has grown much older. He's 21. He's never been operated in hospital, nor has he taken medicine on a regular basis. How do you think his story ends?

a) Juan still has trouble learning things in school, as compared to other boys of his age. He still isn't very smart.

b) Juan has less problems with learning. He's just as smart as other boys of his age.

c) Juan has no problems with learning things. He's a very good student. He's one of the smartest boys of his age."

\section{Procedure}

Data was gathered at the school the children attended. All parents and the school administration were informed about the study's goals and gave their consent. The interviewer presented the stories orally and visually to each participant. Interviews were conducted in a classroom normally used to help children in need of special support; this classroom was chosen because it was a comfortable and quiet place, and also a room the children knew well. Prior to each interview, a relaxed, cordial atmosphere was created to ensure that the child would feel at ease.

After having gathered data to establish a series of categories, we followed the same steps as in our reference study (Lockhart et al., 2002), which also featured the description of reasoned causal explanations on the part of child participants. After an initial categorization, we redefined the categories with our own prototypes, using the verbatim answers provided by the children in our study. We eliminated two categories that proved to be not well-adapted to Spanish culture, and we established two new ones. Thus, for analysis, the children's responses were distributed under a final and definitive system of categories that can be viewed in Table 1 .

Given the novelty of the category system, all responses were recorded by two interviewers to ensure the tool's interrater reliability. With a $95 \%$ level of confidence, differences in what the two interviewers recorded are not statistically significant: the $x$ coefficient is of $.935, .814$ y .869 for the biological, hybrid, and psychological stories respectively.

Table 1. Categories of change predictors.

Categories justifying predicted change

Biological/psychological explanation. The effect of nature on the mind or body of the protagonist is the cause of positive change.

"his finger starts growing / coming out"

"he's eaten a lot"

"he's smarter"

"he thinks a lot", “..."

Explanation due to effort or practice. The change comes about thanks to the pro- Simple continuity across time, due to habit-forming. The trait cannot tagonist's own efforts; it is he who takes control of the problematic situation. be changed.

"he studies a lot"

"he tries really hard"

"he does a lot of exercise", “..."

Explanation due to increasing age or maturity. The change comes about due to the Impossibility of change without intervention. The only chance for transition from childhood to adulthood.

"he's already a grown-up"

"he's grown a lot"

"many years have passed", “...”
Categories justifying predicted stability

ins thervention of nature on the mind or body of the protagonist impossible.

"it can't grow"

"he's lazy/clumsy/stupid”, “...” positive change would lie in an external intervention on the part of other people.

"if they don't sew the finger back on, he won't have it"

"if they don't operate on him ..."

that his wishes become true.

"because he wanted to"

"because that was his wish", "..."

"if he doesn't get constant support..."

"if he doesn't study more than the others...", "..."

Explanation due to willpower. The child in the story wishes so much to change Does not know, or does not answer. 


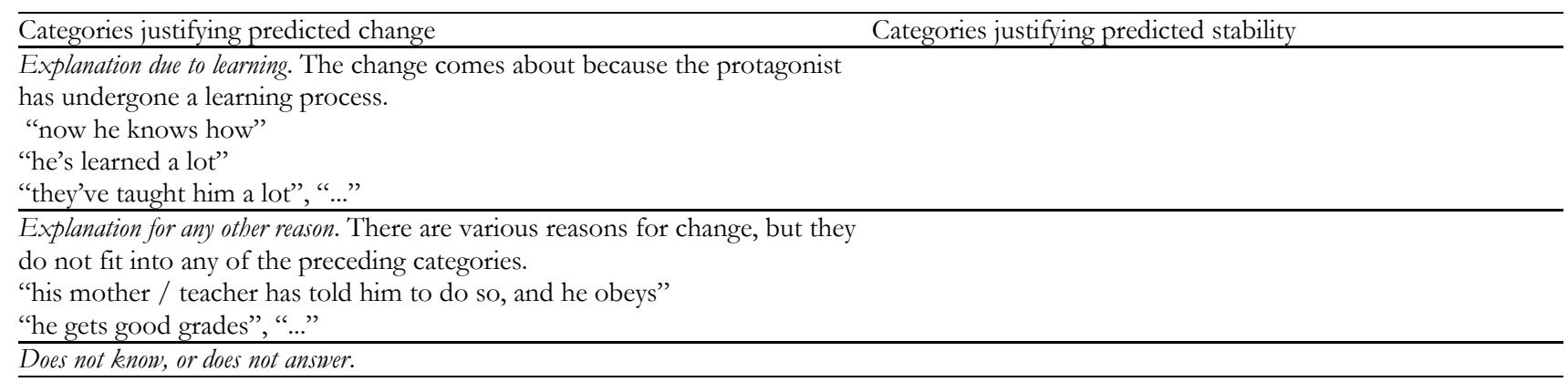

\section{Results}

Table 2 present the response percentages obtained for each one of the situations/stories under consideration. The children were optimistic regarding changes in conditions that are biological (33.8\%), hybrid (55.8\%) and psychological $(55.8 \%)$, although the two latter ones were judged more optimistically than the first type. This can also be ascertained from the Wilcoxon signed-rank test which shows statistically significant differences between biological cases, on the one hand, and hybrid and psychological ones on the other $(\mathrm{Z}=$ 5.064 and $Z=-5.222, p<.001)$, but not between the two latter ones $(Z=0.522, p=.602)$. In general, the responses that imply stability are $44.2 \%$ for the biological situation, but only $7.8 \%$ and $5.2 \%$ for the hybrid and psychological ones respectively.

Table 2. Global predictions according to type of situation.

\begin{tabular}{|c|c|c|c|c|c|c|c|c|c|}
\hline \multirow[b]{3}{*}{ Biológica } & \multirow{2}{*}{\multicolumn{2}{|c|}{$\frac{\text { Stability }}{\text { Pessimistic }}$}} & \multicolumn{4}{|c|}{ Change } & \multirow[b]{2}{*}{$\chi^{2}$} & \multirow{3}{*}{$\frac{\text { g.l. }}{4}$} & \multirow{3}{*}{$\frac{p}{.000}$} \\
\hline & & & & ediate & & mistic & & & \\
\hline & 34 & $44.2 \%$ & 17 & $22.1 \%$ & 26 & $33.8 \%$ & 21.808 & & \\
\hline Híbrida & 6 & $7.8 \%$ & 28 & $36.4 \%$ & 43 & $55.8 \%$ & 11.443 & 4 & .022 \\
\hline Psicológica & 4 & $5.2 \%$ & 30 & $39.0 \%$ & 43 & $55.8 \%$ & 9.691 & 4 & .046 \\
\hline
\end{tabular}

The analysis of the relation between age and type of response for each situation showed differences in all three items. For the biological situation $\left(\chi^{2}{ }_{4}=21.808, p<.001\right)$, the 2nd-grade children tended to provide judgments predicting change $(57.7 \%$ were optimistic judgments and $24.0 \%$ intermediate ones), 4th-grade children displayed a more heterogeneous pattern $(27.6 \%$ optimistic, $31 \%$ intermediate, and $35.3 \%$ pessimistic), whereas 6th-graders mostly predicted stability (pessimistic predictions accounted for $78.3 \%$ of all responses). In the case of the hybrid situation $\left(\chi^{2}=11.443\right.$ $p<.05)$, a majority of the 2 nd-grade children tended to predict change $(80.0 \%$ optimistic, $12 \%$ intermediary); 4thgraders were also optimistic, but to a lesser degree $(51.7 \%$ optimistic and $44.8 \%$ intermediary) whereas 6th-graders continued to predict change (34.8\% optimistic and $52.2 \%$ intermediary), but with the largest percentage of pessimistic responses $(13.0 \%)$. In the case of the psychological situation $\left(\chi^{2}=9.691, p<.05\right)$, a pattern similar to the preceding one emerges: the youngest children were predominantly optimistic $(72.0 \%)$, and responses from older ones were distributed among the intermediate prediction $(56.5 \%)$ and the optimistic one, $(30.4 \%)$, but presented the largest percentage of pessimistic responses $(13.0 \%)$. No statistically significant differences between genders were observed.

Regarding the way the children justified their predictions (Table 3), the majority of children offering optimistic responses to the biological story attributed the cause of positive change to nature itself $(50 \%)$. In the second place the responses concentrated on the explanation by simply increas- ing age, that is, to reach adulthood $(26.2 \%)$. There were a great number of responses indicating the possibility of change for this biological trait; nevertheless, the proportion of optimistic answers in different categories was similar across all groups: the 'change' responses did not display significant differences in terms of argumentative justification. Nevertheless, qualitative differences do appear among age categories in the 'stability' responses to the biological story.

Nine-to-ten-year-olds responded pessimistically (which is to say, in this case, quite realistically) to the negative biological story, and they attributed the main cause of stability to nature itself as invariable (58.3\%) and to simple continuity across time $(25.0 \%)$, without yet providing a solid justification.

Eleven-to-twelve-year-olds generally responded with a much more reasoned argument, justifying their choice of stability by invoking biological continuity (44.4\%) and the impossibility of change without surgical intervention $(38.9 \%)$. Thus, from 4 th to 6 th grade, children orient themselves increasingly towards realism, but still in a groping, intuitive fashion: only by 6th grade are they able to justify their beliefs with a certain degree of soundness in their arguments.

Table 4 presents the results from the hybrid story. In the children's responses one can already note reasonings of a psychological type: as could be expected, they differ from Table 3. In the children's causal explanations of their optimistic beliefs, there is a qualitative difference according to age in the explanation categories of effort, learning and maturity. A greater proportion of younger children respond that 
the hybrid trait would change in a positive sense thanks to learning (40.9\%) and through maturity/coming of age $(27.3 \%)$. From the age of $9-10$ onwards, the change is still mostly attributed to the learning process $(50.0 \%)$; as a second option, however, trust in effort $(14.3 \%)$ and in maturity $(10.7 \%)$ are cited in equal measure, with a slight advantage conferred to the 'effort' category. As to the oldest group (6th graders), the categories obtaining the greatest number of responses are clearly those of change through learning (35.0\%) and through effort $(30.0 \%)$, whereby confidence in change without active effort significantly diminishes.

For the categories related to stability in the hybrid story prediction, we cannot obtain representative conclusions because the amount of pessimistic predictions was too scarce here. The only interesting element to note is that the majority of children who predicted stability justified it with mere continuity across time, without giving other reasons. One could hypothesize that when the children at this age reflect upon psychological aspects which they cannot observe, they do not yet have adequate cognitive tools at their disposal to carry out well-founded introspection. In other words, beliefs in stability based on reasoning - as opposed to the intuitive beliefs we mentioned when we summarized the results from the biological story - would consolidate themselves toward the end of elementary schooling, when the child is increasingly reflecting upon observable phenomena; such reasoning would nevertheless remain incipient during the entire phase if the object of belief is psychological.

Table 3. Causal justifications of predictions associated with the biological story.

\begin{tabular}{lcccc}
\hline Categories justifying stability & \multicolumn{4}{c}{} \\
\hline & $\begin{array}{c}7-8 \text { yrs. } \\
\text { old }\end{array}$ & $\begin{array}{c}9-10 \text { yrs. } \\
\text { old }\end{array}$ & $\begin{array}{c}11-12 \text { yrs. } \\
\text { old }\end{array}$ & Total \\
\hline Biological or psychological & 2 & 7 & 8 & 17 \\
stability & $50.0 \%$ & $58.3 \%$ & $44.4 \%$ & $50.0 \%$ \\
Continuity across time & 1 & 3 & 2 & 6 \\
Impossibility of change & $25.0 \%$ & $25.0 \%$ & $11.1 \%$ & $17.6 \%$ \\
without intervention & 0 & 1 & 7 & 8 \\
Did not know or did not & $.0 \%$ & $8.3 \%$ & $38.9 \%$ & $23.5 \%$ \\
answer & 1 & 1 & 1 & 3 \\
\hline TOTAL & $25.0 \%$ & $8.3 \%$ & $5.6 \%$ & $8.8 \%$ \\
\hline Categories justifying change & 4 & 12 & 18 & 34 \\
\hline Biological / psychological & 11 & 7 & & \\
explanation & $55.0 \%$ & $41.2 \%$ & $60.0 \%$ & $50.0 \%$ \\
Increasing age and maturity & 4 & 5 & 2 & 11 \\
& $20.0 \%$ & $29.4 \%$ & $40.0 \%$ & $26.2 \%$ \\
Willpower & 1 & 1 & 0 & 2 \\
Did not know or did not & $5.0 \%$ & $5.9 \%$ & $.0 \%$ & $4.8 \%$ \\
answer & 4 & 4 & 0 & 8 \\
\hline Total & $20.0 \%$ & $23.5 \%$ & $.0 \%$ & $19.0 \%$ \\
\hline
\end{tabular}

Regarding the psychological story (Table 5), 7-8 yr. olds to mostly tended to justify their optimistic beliefs by evoking the passage of time $(50.0 \%)$. The group of $9-10$ year olds
Table 4. Causal justifications of predictions associated with the hybrid story.

\begin{tabular}{|c|c|c|c|c|}
\hline \multicolumn{5}{|l|}{ Categories justifying stability } \\
\hline & $\begin{array}{l}\text { 7-8 yrs. } \\
\text { old }\end{array}$ & $\begin{array}{l}9-10 \text { yrs. } \\
\text { old }\end{array}$ & $\begin{array}{l}11-12 \text { yrs. } \\
\text { old }\end{array}$ & Total \\
\hline$\overline{\text { Biolo }}$ & $\begin{array}{c}0 \\
0\end{array}$ & 1 & 0 & 1 \\
\hline & $.0 \%$ & $100.0 \%$ & $.0 \%$ & $16.7 \%$ \\
\hline Continuity across time & $50.0 \%$ & $.0 \%$ & $\begin{array}{c}3 \\
100.0 \%\end{array}$ & $\begin{array}{c}4 \\
66.7 \%\end{array}$ \\
\hline know or did not & $\begin{array}{c}1 \\
50.0 \%\end{array}$ & $\begin{array}{c}0 \\
.0 \%\end{array}$ & $\begin{array}{c}0 \\
.0 \%\end{array}$ & $\begin{array}{c}1 \\
16.7 \%\end{array}$ \\
\hline Total & 2 & 1 & 3 & 6 \\
\hline \multicolumn{5}{|l|}{ Categories justifying change } \\
\hline sychological & $\begin{array}{c}3 \\
13.6 \%\end{array}$ & $\begin{array}{c}4 \\
14.3 \%\end{array}$ & $\begin{array}{c}3 \\
15.0 \%\end{array}$ & $\begin{array}{c}10 \\
14.3 \%\end{array}$ \\
\hline Effort/practice & $\begin{array}{c}1 \\
4.5 \%\end{array}$ & $\begin{array}{c}4 \\
14.3 \%\end{array}$ & $\begin{array}{c}6 \\
30.0 \%\end{array}$ & $\begin{array}{c}11 \\
15.7 \%\end{array}$ \\
\hline Increased age and maturity & $\begin{array}{c}6 \\
27.3 \%\end{array}$ & $\begin{array}{c}3 \\
10.7 \%\end{array}$ & $\begin{array}{c}3 \\
15.0 \%\end{array}$ & $\begin{array}{c}12 \\
17.1 \%\end{array}$ \\
\hline Learning & $\begin{array}{c}9 \\
40.9 \%\end{array}$ & $\begin{array}{c}14 \\
50.0 \%\end{array}$ & $\begin{array}{c}7 \\
35.0 \%\end{array}$ & $\begin{array}{c}30 \\
42.9 \%\end{array}$ \\
\hline Other $\mathrm{r}$ & $\begin{array}{c}1 \\
4.5 \%\end{array}$ & $\begin{array}{c}3 \\
10.7 \%\end{array}$ & $\begin{array}{c}1 \\
5.0 \%\end{array}$ & $\begin{array}{c}5 \\
7.1 \%\end{array}$ \\
\hline $\begin{array}{l}\text { Did not know or did not } \\
\text { answer }\end{array}$ & $\begin{array}{c}2 \\
9.1 \%\end{array}$ & $\begin{array}{c}0 \\
.0 \%\end{array}$ & $\begin{array}{c}0 \\
.0 \%\end{array}$ & $\begin{array}{c}2 \\
2.9 \% \\
\end{array}$ \\
\hline Total & 22 & 28 & 20 & 70 \\
\hline
\end{tabular}

tended to trust that learning would make things better $(31.0 \%)$, with second place accorded to personal effort $(27.6 \%)$, yet still with a high percentage of pupils whose sole reason for optimism would be the passage of time $(24.1 \%)$. The next qualitative leap occurs around 6th grade, where $50.0 \%$ of the responses concentrate on personal effort and the acquisition of practice. The learning process remains important for this group as well $(35.0 \%)$.

Table 5. Causal justifications of predictions associated with the psychological story.

\begin{tabular}{|c|c|c|c|c|}
\hline \multicolumn{5}{|l|}{ Categories justifying stability } \\
\hline & $7-8$ & $9-10$ & $11-12$ & \\
\hline & \multicolumn{4}{|c|}{ yrs. old yrs. old yrs. old lotal } \\
\hline \multirow[t]{3}{*}{ Continuity across time } & 1 & & 3 & 4 \\
\hline & $100.0 \%$ & & $100.0 \%$ & $100.0 \%$ \\
\hline & 1 & & 3 & 4 \\
\hline \multicolumn{5}{|l|}{ Categories justifying change } \\
\hline \multirow[t]{2}{*}{ Effort/practice } & 0 & 8 & 10 & 18 \\
\hline & $.0 \%$ & $27.6 \%$ & $50.0 \%$ & $24.7 \%$ \\
\hline \multirow[t]{2}{*}{ Increased age and maturity } & 12 & 7 & 1 & 20 \\
\hline & $50.0 \%$ & $24.1 \%$ & $5.0 \%$ & $27.4 \%$ \\
\hline \multirow[t]{2}{*}{ Willpower } & 0 & 1 & 0 & 1 \\
\hline & $.0 \%$ & $3.4 \%$ & $.0 \%$ & $1.4 \%$ \\
\hline \multirow[t]{2}{*}{ Learning } & 3 & 9 & 7 & 19 \\
\hline & $12.5 \%$ & $31.0 \%$ & $35.0 \%$ & $26.0 \%$ \\
\hline \multirow[t]{2}{*}{ Other reasons } & 4 & 3 & 2 & 9 \\
\hline & $16.7 \%$ & $10.3 \%$ & $10.0 \%$ & $12.3 \%$ \\
\hline \multirow[t]{2}{*}{ Did not know or did not answer } & 5 & 1 & 0 & 6 \\
\hline & $20.8 \%$ & $3.4 \%$ & $.0 \%$ & $8.2 \%$ \\
\hline Total & 24 & 29 & 20 & 73 \\
\hline
\end{tabular}




\section{Discussion and conclusions}

In this study we sought to further investigate the evolution of optimism in childhood, one of this construct's least researched aspects (Chang, 2002). We have studied the optimistic bias displayed by children when they reason about reality - a phenomenon that has been observed in other countries but which had not yet been investigated in Spain. Thus this study offers relevant data regarding the evolution of optimism from an age-related perspective as well as in aspects of content, taking into account the predictions and the justifications offered by children for the possible changes they predict. Thus, younger children in our study do not perceive deterministic differences of some traits as compared to others, and they have not estimated that there are large differences in terms of potential stability when comparing biological and psychological traits. Older children, however, attribute greater stability to biological traits and propose more realistic arguments to uphold their predictions.

If we further reflect on observed differences among age groups, we can conclude that younger children (7-8 years old) firmly believe that negative traits will change in a positive direction in the near future, independently of the type of trait (biological or psychological). That optimistic tendency suggests that these children focus their attention on trait variability independently of trait type. However, from the age of 9 onwards, the nature of the trait - either biological or psychological in origin - seems to be the variable which tends to condition their belief about its malleability in the future: this would uphold the idea of distinction among biological, hybrid and psychological domains (Erickson et al, 2010; Gelman, 2004; Gelman et al., 2007; Lockhart et al., 2002).

From that age on, and more evidently when approaching the end of elementary education, children's beliefs about trait stability seem to be determined by the nature they ascribe to each trait. In other words, the more realistic view of the world leads them to regard certain traits as more susceptible to change, and other ones as permanent. This is the moment from which their judgments about the future will take the entire scope of the stability-variability dimension into account. Similar studies, including Heyman \& Gelman (2000), Gelman (2004), and Shtulman \& Carey (2007), have investigated the discriminative capacity displayed by children up to 8 years old when distinguishing between impossible and improbable events in function of natural laws. According to these authors, young children differ markedly from adults in terms of the degree to which their world knowledge takes domain specificity into account. When young children evaluate the probability of occurrence of an event, they do not distinguish whether it is possible or impossible according to natural laws because they do not ascribe different origins to real or imaginary events.

Our results reveal further differences. On the one hand, optimistic responses do not attain the same percentages for all analyzed traits alike. Thus, for instance, biological traits pertaining to the physical world obey more realistic patterns than psychological or hybrid traits. It seems as if children, from early childhood onward, already tend to make causal inferences resorting to knowledge areas that differentiate between the physical, the biological and the psychological domain (Erickson, Keil \& Lockhart, 2010; Lockhart et al., 2013). Such explanations are similar in children of the same age, but the reasoning they provide for their justification incorporates more and more dimensions as they progressively accumulate personal experience and as their capacity for logic improves. This tendency first becomes evident in their predictions of stability - and when they predict change, such older children also envision the possibility that the individual could assume responsibility for it when possible.

This differential change pattern might uphold the hypothesis that as children gradually develop greater cognitive capacities these tend to interact with experience. Within that process, children learn that psychological viz. behavioral traits are easier to modify thanks to effort, for instance, whereas other dimensions such as the biological domain cannot be modified as easily. Our results have likewise shown that younger children's predictions are of a different nature than those made by adults, and that they differ among children according to the type of situation: their responses depend on the nature of the situation. The content thereby produced can become a specific domain (likewise associated with essentialism, which we referred to in the introduction).

Other studies confirm such findings (Barnett, Sonnentag, Wadian, Jones \& Langley, 2015; Lockhart et al. 2008, 2013) highlighting specific domains and their development as age progresses. Thus, Lockhart et al. (2013) and Barnett et al. (2015) studied predictions associated with effort, or with the use of medicinal substances or with support from the outside: these areas are all viewed differently according to age. Furthermore, Lockhart et al. (2008) found that predictions associated with effort differ among cultures, and that such differences emerge with age.

As a final conclusion, we note that our results are very similar to those of other authors (Boseovski, 2012; Dweck \& Leggett, 1988; Cole et al., 2008; Heyman \& Gelman, 2000; Lockhart et al., 2002; 2008; Sato \& Wakebe, 2014) whose studies we used as references. We have commented on their theoretical considerations by adding a few nuances. Since this study was carried out in the elementary education system in Spain, it enables us to conduct optimism studies within the context of our own country, providing us with a qualitative explanation geared to our own culture. We should note, however, that this study of optimistic beliefs in children does not yet address the theme of attributional style displayed by adolescents or adults as related to their personal beliefs, neither does our work have a direct link with dispositional optimism. Thus, although both of these kinds of optimism can be associated with the exercise of control (Gillham \& Reivich, 2004), we cannot assume the existence of a direct parallel between children's voiced expectations in these ages - influenced, as they are, by optimistic bias - and dispositional optimism. Children can experience a certain feeling of con- 
trol and mastery of tasks (Boseovski, 2010), but these two types of optimism are qualitatively different (Orejudo \& Teruel, 2009). Thus, on the one hand, the type of justification provided by children evolves notably with age - not only in terms of outcome, but most importantly in terms of the way they explain the causes thereof. On the other hand, in this context no research has yet compared the attributions children make about other people (such as the characters in the stories in this study) with those they make about themselves. The literature supports the hypothesis that children's reasoning about themselves in these ages reflects a greater bias than when they reason about others; in other words, positive personal traits are ascribed in greater measure to internal causes - which are more stable - than traits displayed by others (Diesendruck \& Lindenbaum, 2009).

Even though our results have relevance, we view them with precaution due to certain limitations. First of all, we have obtained data reflecting the stability of these children's beliefs along the time axis, but not concerning their category system: therefore we do not know how stable these arguments actually are. It would also be fruitful to enlarge the instrument's capacities by adding new biological, psychological and hybrid story situations, and to validate it, in order to see whether our hypothesis of specific domains is confirmed. And since we are dealing here with an intentional sample, there is likewise less guarantee that is representative; therefore, it would be advisable to conduct replication studies.

Neither should we overlook the fact that the children in this sample were reasoning, via our tool, about events which

\section{References}

Ato, E., Galián, M.D. \& Huéscar, E. (2007). Relaciones entre estilos educativos, temperamento y ajuste social en la infancia: Una revisión. Anales de Psicología, 23, 33-40.

Barnett, M.A., Sonnentag, T.L., Wadian, T.W., Jones, T.L. \& Langley, C.A. (2015). Children's Perceptions of hypothetical peers with undesirable characteristics: Role of the peers desire to change, source of effort to change, and outcome. Journal of Genetic Psychology, 176, 55-63. doi: 10.1080/00221325.2014.1002751

Brissette, I., Carver, M.F. \& Scheier, C.S. (2002). The role of Optimism in social network development, coping and psychosocial adjustement during a life transition. Journal of Personality and Social Psychology, 82, 102-111. DOI: 10.1037//0022-3514.82.1.102.

Boman, P. \& Yates, G.C.R. (2001). Optimism, hostility, and adjustment in the first year of high school. British Journal of Educational Psychology, 71, 401-411. doi: 10.1348/000709901158587

Boman, P., Smith, D.C. \& Curtis, D. (2003). Effects of pessimism and explanatory style on development of anger in children. School Psychology International, 24, 80-94. doi: 10.1177/0143034303024001581

Boseovski, J.J. (2012). Trust in testimony about strangers: Young children prefer reliable informants who make positive attributions. Journal of Experimental Child Psychology, 111, 543-551. doi: 10.1016/j.jecp.2011.10.008

Bruce, A.E., Cole, D.A., Dallaire, D.H., Jacquez, F.M., Pineda, A.Q. \& LaGrange, B. (2006). Relations of Parenting and Negative Life Events to Cognitive Diatheses for Depression in Children. Journal of Abnormal Child Psychology, 34, 321-333. doi: 10.1007/s10802-006-9019-x

Chang, E.C. (2002) Optimism \& Pessimism. Implications for Theory, Research, and Practice. Washington, DC: APA. doi: 10.1111/j.1467-9507.2008.00494.x

Chorpita, B.F. \& Barlow, D. H. (1998). The development of anxiety: The role of control in the early environment. Psychological Bulletin, 124, 3-21. had occurred to other people. Even though the children could regard those people as prototypically similar to themselves, they had to make inferences by placing themselves in a hypothetical situation. Another line of investigation would thus consist in relating the hypothetical stories featured in the interviews to events actually experienced by the children, framing the whole within a more open, ecological format. That would help us to avoid the risk that the children might have been eventually obeying a bias by placing themselves "in the shoes" of others. And in view of the abovementioned arguments concerning the continuity of such beliefs across time, it would be appropriate to find out which contextual or cultural factors encourage a progression toward more stable and realistic systems of beliefs (Boseovski, 2010; Gelman et al., 2007), including the attributional style displayed by adults, the important role played by the educational system, and the child's personal history. Along these lines, Barnett et al. (2015) have found that judgments made about peers initially display optimistic bias; as the children grow older, however, they start incorporating information acquired from their own experience into their attributions. Finally, Newman, De Freitas \& Knobe (2015) found that the moral value ascribed by children to the situations they are asked to judge also exerts an influence on their justifications, thus adding an additional element to our understanding of optimism as a truly important factor in psychological evolution.

Cole, D.A., Ciesla, J.A., Dallaire, D.H., Jacquez, F.A., Pineda, A.Q., LaGrange, B., Truss, A.E., Folmer, A.S., Tilghman-Osborne, C. \& Felton, J.W. (2008). Emergence of Attributional Style and Its Relation to Depressive Symptoms. Journal of Abnormal Psychology, 117, 16-31. doi: 10.1037/0021-843X.117.1.16

Deeb, I., Segall, G., Birnbaum, D., Ben-Eliyahu, A., \& Diesendruck, G. (2011). Seeing isn't believing: The effect of intergroup exposure on children's essentialist beliefs about ethnic categories. Journal of Personality and Social Psychology, 101, 1139-1156. doi: 10.1037/a0026107

Diesendruck, G. \& Eldror, E. (2011). What children infer from social categories. Cognitive Development, 26, 118-126. DOI: 10.1016/j.cogdev.2010.11.001

Diesendruck, G., \& Lindenbaum, T. (2009). Self-protective Optimism: Children's Biased Beliefs about the Stability of Traits. Social Development, 18, 946-961. doi: 10.1111/j.1467-9507.2008.00494.x

Del Rio, M. F. \& Strasser, K. (2007). ¿Tienen los niños una teoría esencialista acerca de la pobreza? Psykhe, 16, 139-149.

Dweck, C.S. \& Leggett, E.L. (1988). A social-cognitive approach to motivation and personality. Psychological Review, 95, 256-273. doi: 10.1037/0033-295X.95.2.256

Erickson, J.E., Keil, F.C. \& Lockhart, K.L. (2010). Sensing the Coherence of Biology in Contrast to Psychology: Young Children's Use of Causal Relations to Distinguish Two Foundational Domains. Child Development, 81, 390-409. doi: 10.1111/j.1467-8624.2009.01402.x

Feldman, D.F. \& Kubota, M. (2015). Hope, self-efficacy, optimism, and academic achievement: Distinguishing constructs and levels of specificity in predicting college grade-point average. Learning and Individual Differences, 37, 210-216. doi: 10.1016/j.lindif.2014.11.022 
Gelman, S. (2004). Psychological essentialism in children. Trends in Cognitive Sciences, 8, 404-409. doi: 10.1016/j.tics.2004.07.001

Gelman, S.A., Heyman, G.D. \& Legare, C.H. (2007). Developmental changes in the coherence of essentialist beliefs about psychological characteristics. Child Development, 78, 757-774. doi: 10.1111/j.14678624.2007.01031.x

Gillham, J. \& Reivich, K. (2004). Cultivating optimism in childhood and adolescence. The Annals of the American Academy, 391, 146-163. doi: 10.1177/0002716203260095

Gillham, J.E., Reivich, K.J., \& Shatté, A. (2002). Building optimism and preventing depressive symptoms in children. En Chang. (Ed.), Optimism o Pessimism. Implications for Theory, Research, and Practice (pp. 321-346). Washington, DC: APA.

Gillham, J., Shatté, A., Reivich, K. \& Seligman, M.E.P (2002) Optimism, pessimism, and explanatory style. En E.C. Chang. (Ed.), Optimism \& Pessimism. Implications for Theory, Research, and Practice (pp. 53-75). Washington, DC: APA.

Heyman, G. \& Dweck, C. (1998). Children's thinking about traits: Implications for judgements of the self and others. Child Development, 64, 391403. doi: $10.1111 / j .1467-8624.1998 . t b 06197 . x$

Heyman, G. \& Gelman, S. (2000). Beliefs about the origins of human psychological traits. Developmental Psychology, 36, 663-678. doi: 10.1037/0012-1649.36.5.663

Hirschfeld, L.A. (1995). Do children have a theory of race? Cognition, 54, 209-252. doi: 10.1016/0010-0277(95)91425-R

Huan, V.S., Yeo, L.S., Ang, R. P. \& Chong, W. H. (2006). The influence of dispositional optimism and gender on adolescents' perception of academic stress. Adolescence, 41, 533-546.

Karmiloff-Smith, A. (1994). Más allá de la modularidad. Madrid: Alianza.

Lockhart, K.L, Chang, B. \& Story, T. (2002). Young children's beliefs about the stability of traits: Protective Optimism? Child Development, 73, 14081430. doi: 10.1111/1467-8624.00480

Lockhart, K.L. , Keil, F.C. \& Aw, J. (2013). A bias for the natural? Children's beliefs about traits acquired through effort, bribes, or medicine, Developmental Psychology, 49, 1669-1682. doi: 10.1037/a0030769

Lockhart, K.L., Nakashima, N., Inagaki, K. \& Keil, F.C. (2008). From ugly duckling to swan? Japanese and American beliefs about the stability and origins of traits. Cognitive Development, 23, 155-179. doi: 10.1016/j.cogdev.2007.08.001

Newman, G.E., Bloom, P. \& Knobe, J. (2014). Value judgments and the true self. Personality and Social Psychology Bulletin, 40, 203-216. doi: $10.1177 / 0146167213508791$
Newman, G.E., De Freitas, J. \& Knobe, J. (2015). Beliefs about the true self explain asymmetries based on moral judgment. Cognitive Science, 39 , 96-125. doi: 10.1111/cogs.12134

Orejudo, S., Puyuelo, M., Fernández-Turrado, T., \& Ramos, T. (2012). Optimism in adolescence: A cross-sectional study of the influence of family and peer group variables on junior high school students. Personality and Individual Differences, 52, 812-817. doi: 10.1016/j.paid.2012.01.012

Orejudo, S., \& Teruel, M. P. (2009). Una mirada evolutiva al optimismo en la edad escolar: Algunas reflexiones para padres, educadores e investigadores. Revista Interuniversitaria de Formación del Profesorado,66, 129-158.

Peraita, H. (1985). Representación de conceptos: rasgos y esquemas. Infancia y Aprendizaje, 31-32, 187-202. doi: 10.1080/02103702.1985.10822092

Peraita, H. (2009). Conceptos y categorización. En M.J. González Labra. In troducción a la Psicología del Pensamiento (pp. 185-234). Madrid: Editorial Trotta.

Pérez Álvarez, Marino (2012). La psicología positiva: magia simpática. Papeles del Psicólogo, 33, 183-201.

Rand, K.L. (2009). Hope and optimism: Latent structures and influences on grade expectancy and academic performance. Journal of Personality, 77, 231-260. doi: 10.1111/j.1467-6494.2008.00544.x

Romero, E. (2005). ¿Qué unidades debemos emplear?. Las “dos disciplinas" de la psicología de la personalidad. Anales de Psicología, 21, 244-258.

Roberts, M.C., Brown, K.J., Johnson, R.J. \& Reinke, J. (2005). Positive Psychology for children. Development, Prevention and Promotion. En Snyder \& López (Eds.), Handbook of positive psychology (pp. 663-675). Oxford: University Press.

Sato, T. \& Wakebe, T. (2014). How do young children judge intentions of an agent affecting a patient? Outcome-based judgment and positivity bias. Journal of Experimental Child Psychology, 118, 93-100. doi: 10.1016/j.jecp.2013.09.004

Scheier, M.F. \& Carver, C.S. (1992). Effects of optimism on psychological and physical well-being: Teoretical overview and empirical update. $C o g$ nitive Therapy and Research, 16, (2), 201-228. doi: 10.1007/BF01173489

Seligman M.E.P. \& Csikszentmihalyi. M. (2000) Positive Psychologist. An introduction. American Psychologist, 55, 5-14. doi: 10.1037/0003066X.55.1.5

Shtulman, A. \& Carey, S. (2007). Improbable or Impossible? How children reason about the possibility of extraordinary events. Child Development, $78,1015-1032$

(Article received: 1-12-2014; revised: 9-6-2015; accepted: 28-10-2015) 